EPJ Web of Conferences 52, 01002 (2013)

DOI: $10.1051 /$ epjconf $/ 20135201002$

(C) Owned by the authors, published by EDP Sciences, 2013

\title{
New Results from the CMS experiment
}

\author{
Albert De Roeck ${ }^{1, a}$ \\ ${ }^{1}$ CERN, Switzerland
}

\begin{abstract}
We'll present recent results from the CMS experiment on measurements, such as the total inelastic pp cross section, diffractive phenomena, leading particle spectra and energy flow in the forward region, measurements relevant for tuning of Monte Carlo programs used for cosmic rays studies. We'll also give a brief overview of the searches for new physics and the recent results on the discovery of a higgs-like particle with a mass of $125 \mathrm{GeV}$.
\end{abstract}

\section{Slides}

The slides of the talk can be found on the website of the symposium ISVHECRI 2012:

https://indico.desy.de/conferenceOtherViews.py?view=standard\&confId=4594

aderoeck@mail.cern.ch

This is an Open Access article distributed under the terms of the Creative Commons Attribution License 2.0, which permits unrestricted use, distribution, and reproduction in any medium, provided the original work is properly cited. 